\title{
Water Conservation with Rainwater Harvesting System in Lampung Province (Case Study in State Polytechnic of Lampung Campus Area)
}

\author{
Aniessa Rinny Asnaning1, Surya ${ }^{2}$, Andy Eka Saputra², Destieka Ahyuni ${ }^{4}$ \\ Affiliation: Agricultural Technology ${ }^{123}$, Crop Production ${ }^{4}$, State Polytechnic of Lampung, Lampung, \\ Indonesia \\ Corresponding author: aniessa.rinny@ polinela.ac.id
}

\begin{abstract}
The excessive quantity of groundwater utilization leads to significantly reduced groundwater availability. In another aspect of a tropical country, Indonesia has a reasonably high rainfall in the rainy season. The problem of this research is that the rainwater that has not been utilized and managed to maximize so that only becomes runoff. The community can utilize rainwater for the daily need. This paper presents methods and prototypes of rainwater harvesting and collection at the research locus. Methods of rainwater collection can be done with a rainwater harvesting system in the form of gutter mounted on the roof of the building as a tool to direct the flow of rainwater on the roof to the shelter. Rainfall compared to the roof area, will produce the volume of stored rainwater reservoir as a parameter. The novelty proposed in this study is the value and variable of water parameters in the case study of research implementation This case study was carried out in one of the buildings at Lampung State Polytechnic. The building has $96.72 \mathrm{~m}^{2}$ of roof area with daily average rainfall equal to $8.6 \mathrm{~mm} /$ day (January to May 2018 period). Hence rainwater potency which can be accommodated per day by society is equal to $0.582 \mathrm{~m}^{3} /$ month with assumption only $70 \%$ water rain that collected because of water loss. In the rainy season, the volume of actual rainwater that can be collected as much as $0,831 \mathrm{~m}^{3} / \mathrm{month}$ by ignoring water loss due to evaporation. The quality of rainwater analyzed based on several parameters is $\mathrm{pH} 4.4$, temperature $27,5^{\circ} \mathrm{C}$, turbidity $2.02 \mathrm{NTU}$, total dissolved solids $20.48 \mathrm{ppm}$, iron $<0.110 \mathrm{ppm}$, calcium $3.36 \mathrm{mg} / \mathrm{l}$, magnesium $0.233 \mathrm{mg} / \mathrm{l}$, lead $<0,021 \mathrm{ppm}$, hardness 3.69 $\mathrm{mg} / \mathrm{l}$, and total coliform $6,1 \mathrm{CFU} / 100 \mathrm{ml}$. Testing of the results of this study conducted by testing water quality standards compliance with the regulation of the Indonesia Health Minister number 32 of 2017. Test results show that rainwater can be directly utilized for sanitary hygiene purposes with the improvement of $\mathrm{pH}$ value.
\end{abstract}

\section{Introduction}

Most of the world community utilizes groundwater taken through wells to meet daily clean water needs. Groundwater is a source of clean water that naturally has been purified through various rock layers so that people use it more directly. Comparison between groundwater exploration and unbalanced recharge makes groundwater more difficult to obtain especially during the dry season. Another way to get water is to utilize surface water from rivers and other water bodies which are then carried out by physical, 
biological and chemical processing systems. However, the relatively poor quality of surface water at this time makes the refining process complicated and requires very high costs.

Water sources on earth are not only groundwater and surface water but also atmospheric water (rainwater). The community can also utilize atmospheric water or rainwater that falls to the earth's surface with only a little purification effort. However, the use of rainwater is still infrequent. Falling rainwater is mostly not utilized and only becomes a surface runoff flow. As a tropical country, Indonesia has a high rainfall potential every year to be utilized by the community. One method to be able to collect rainwater is to build a Rainwater Harvesting System (RWHS).

The purpose of this study is to get the actual accommodated volume of rainwater. Therefore compare it with the calculation according to the broadly applicable equation, and get the quality of used rainwater according to the Minister of Health Regulation number 32 of 2017 concerning Quality Standards for Environmental Health and Health Requirements for Water for Sanitary Hygiene, Swimming Pool, and Public Baths.

\section{Related Research}

Rainwater Harvesting (RWH) is the process of intercepting, flowing and storing rainwater for future use. Some facilities and infrastructure that can be used to harvest rainwater include storage tanks, reservoirs, small reservoirs or artificial ponds (Kharisma et al., 2016). Research contributions and positions related to rainwater harvesting and filtration methods were obtained from another researcher. Nachshon et al. in 2016 discuss the impact of rainwater harvesting on urban hydrological systems. The method used is surface runoff estimation. Two harvesting system discussed from this paper: (1) storage of harvested water; And (2) infiltration of water harvested into groundwater (Nachshon, Netzer, \& Livshitz, 2016). Rosmin in 2015 using rainwater harvesting (RWH) system as a method of collecting rainwater and storing rainwater into the tank before being reused to generate electricity. This publication produces a system, which is designed and built to have good performance regarding producing constant voltage and current from rainwater harvesting (Rosmin, Jauhari, Mustaamal, Husin, \& Hassan, 2015). Another research use of RWH for food, drinking in a city area. The purpose of this study was to look at the effects and radioactive elements from RWH use. The results of this study note that Radon (Rn) active compounds are found in RWH if no periodic maintenance is carried out (Al-Khatib, Al Zabadi, \& Saffarini, 2017).

RWH utilization is also carried out in other fields. The publication by Lam in 2015 discussed the potential for using rainwater harvesting in a temperature reduction in a city. The method used is Area Precipitation per Demand Ratio (APDR) and Geographic Information System (GIS) in mapping the potential utilization of rainwater. The results of the study stated that RWH utilization was significant in reducing the temperature and environmental damage conditions ((An, Lam, Hao, Morakinyo, \& Furumai, 2015). Research into the use of RWH as a solution to water scarcity in a country was carried out by Lee in 2016. That paper estimates that rainwater harvesting will play a role as an alternative water source in a country. The challenges of developing rainwater harvesting are environmental, policy, economic, social and technical (Lee, Mokhtar, Mohd Hanafiah, Abdul Halim, \& Badusah, 2016). There is a development in utilizing RWH with another technology. A paper written by Mahmood in 2017, mentioning water harvesting is a simple, energy-efficient and cost-effective solution to meet domestic demand for drinking water and water in rural communities. The method used is the rainfall climatology, the concept of remote sensing and water balance. This study uses other climatological data in the from satellite to initiating a place to build a distributed rainwater harvesting system (Mahmood \& Hossain, 2017). RWH technology is believed to be a solution to water scarcity in the future. Campisano in 2017 examined the need to design RWH that currently exists only to conserve water. Even though RWH is the answer to the solution for water needs in the future (Campisano et al., 2017). 


\section{Research Method}

The used research methods for the provision of clean water settlement with rainwater harvesting method are shown in Figure 1:

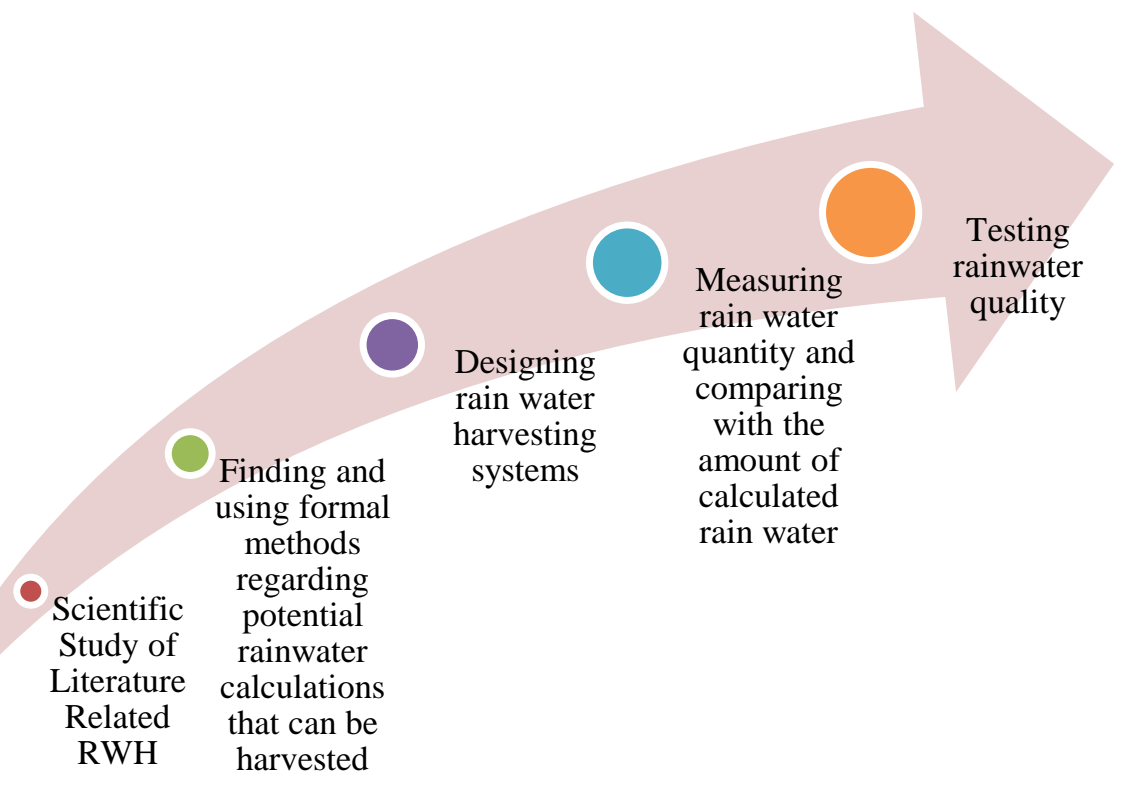

Figure 1. Research Methods

The research was conducted at the Soil Mechanics Laboratory, Lampung State Polytechnic as a place to model rainwater harvesting systems to measure the volume of rainwater that can be accommodated in a building's roof area significantly. Rainwater management in this study consists of a tool used to collect rainwater from the roof by using gutters around the roof of the building and connected with PVC pipes to the reservoir as shown in Figure 2.

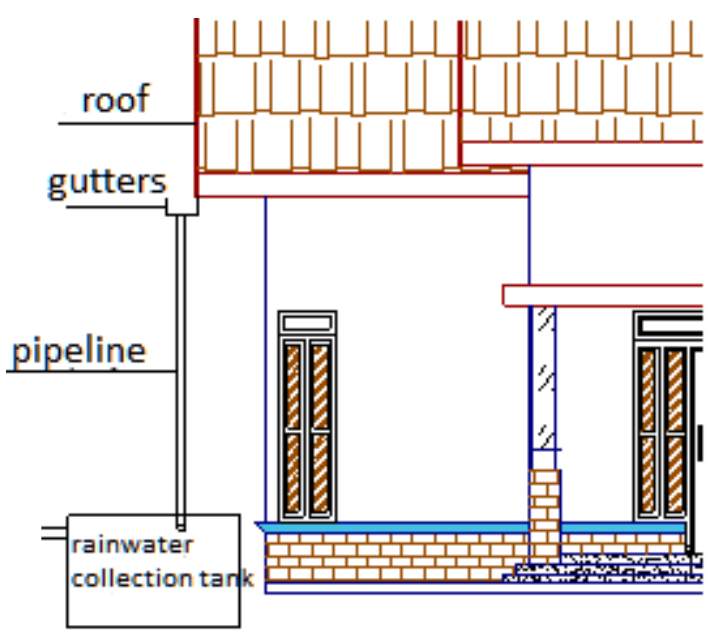

Figure 2. Rainwater Harvesting Design 
Then the results of measured rainwater volume will be compared with the potential amount of collected rainwater from the roof of the building per month by using equation from secondary data of rainfall obtained from Lampung State Polytechnic Climatology Station. The potential amount of collected rainwater is calculated using the following formula:

$\mathrm{VR}=\frac{\mathrm{R} \times \mathrm{Hra} \times \mathrm{Rc}}{1000}$

Where:

$\mathrm{VR}=$ volume of rainwater collected per monthly building $\left(\mathrm{m}^{3}\right)$

$\mathrm{R}=$ monthly rainfall depth $(\mathrm{mm})$

$\mathrm{Hra}=$ roof area of the building $\left(\mathrm{m}^{2}\right)$

$\mathrm{Rc}=$ runoff coefficient is 0.7 assuming that $30 \%$ of the collected rainwater will evaporate and disappear on its way from gutters to reservoirs (Lizarraga-Mendiola et al., 2015).

Rainwater quality values will also be analyzed using standards from the Minister of Health Regulation number 32 of 2017 to find out the proper use of the rainwater. Primary and secondary data collection is carried out in the rainy season around January to May 2018 on every rainy day.

\section{Result and Discussion}

Daily rainfall during the rainy season from January to May 2018 is presented in Figure 3.

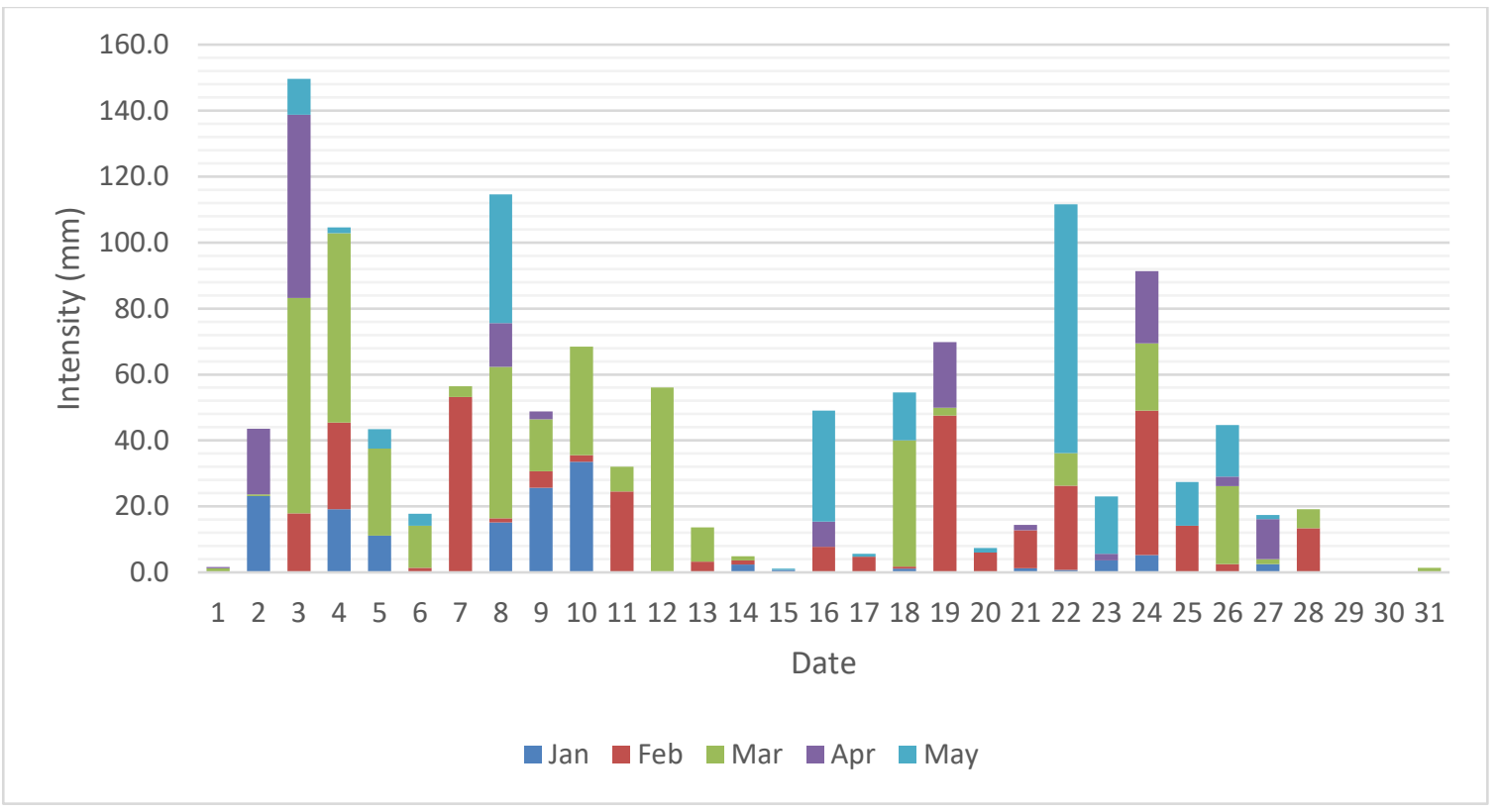

Figure 3. Daily rainfall during the rainy season

The rainiest day occurs in March 2018 with a total of 22 days in a month. The fewest rainy days occur in April 2018 with an amount of 11 days in a month. The highest rainfall occurs on May 22, 2018, at $75.4 \mathrm{~mm}$. 
The calculation of the roof area used as a model is $96.72 \mathrm{~m} 2$ (with a roof length of $15.6 \mathrm{~m}$ and a roof width of $6.2 \mathrm{~m}$ ). Calculation of the potential monthly volume of rainwater (VR) that can be accommodated assuming a 30\% water loss as in the previous formula, is presented in Table 1.

Table 1. The potential volume of rainwater collected per monthly building

\begin{tabular}{cccccc}
\hline Jan & Feb & Mar & Apr & May & $\begin{array}{c}\text { Average Potential } \\
\text { Volume of Rainwater } \\
\left(\text { VR) }\left(\mathbf{m}^{\mathbf{3}}\right)\right.\end{array}$ \\
\hline 0,318 & 0,759 & 0,961 & 0,361 & 0,512 & 0,582 \\
\hline
\end{tabular}

Based on the calculations, during the rainy season, the average volume of rainwater can be collected as much as $0.582 \mathrm{~m}^{3}$ per month from the roof area of $96.72 \mathrm{~m}^{2}$. The actual volume of rainwater that can be accommodated based on observations is presented in Table 2.

Table 2. The volume of Measured Rainwater

\begin{tabular}{cccccc}
\hline Jan & Feb & Mar & Apr & May & $\begin{array}{c}\text { Average } \\
\text { Measured } \\
\text { Rainwater } \\
\text { Volume }\left(\mathbf{m}^{3}\right)\end{array}$ \\
\hline 0,455 & 1,084 & 1,372 & 0,515 & 0,732 & 0,831 \\
\hline
\end{tabular}

Based on the measurement results, the average volume of actually collected rainwater is $0.831 \mathrm{~m}^{3} /$ month. Comparison of the volume of rainwater that can be accommodated based on the results of observations with the potential of rainwater from the calculation results shows a difference in yield of $30 \%$ due to the use of runoff coefficient value of 0.7 . The amount of lost rainwater that drops assumed $30 \%$ due to evaporation. However, in reality, in the rainy season, rainwater can collect as much as $100 \%$ of the number of rainfalls. The comparison values can be seen in Table 3 .

Table 3. Comparison of the volume of calculated and measured rainwater

\begin{tabular}{|c|c|c|c|c|c|c|c|c|c|c|c|c|c|c|}
\hline Jan & & e & Feb & & e & Mar & & e & Apr & & e & May & & e \\
\hline $100 \%$ & R W & & $100 \%$ & R W & & $100 \%$ & R W & & $100 \%$ & R W & & $100 \%$ & R W & \\
\hline $\begin{array}{l}\text { VR } \\
\left(\mathrm{m}^{3}\right)\end{array}$ & $\begin{array}{l}\text { Vol. } \\
\left(\mathrm{m}^{3}\right)\end{array}$ & & $\begin{array}{l}\text { VR } \\
\left(\mathrm{m}^{3}\right)\end{array}$ & $\begin{array}{l}\text { Vol. } \\
\left(\mathrm{m}^{3}\right)\end{array}$ & & $\begin{array}{l}\text { VR } \\
\left(\mathrm{m}^{3}\right)\end{array}$ & $\begin{array}{l}\text { Vol. } \\
\left(\mathrm{m}^{3}\right)\end{array}$ & & $\begin{array}{l}\text { VR } \\
\left(\mathrm{m}^{3}\right)\end{array}$ & $\begin{array}{l}\text { Vol. } \\
\left(\mathrm{m}^{3}\right)\end{array}$ & & $\begin{array}{l}\text { VR } \\
\left(\mathrm{m}^{3}\right)\end{array}$ & $\begin{array}{l}\text { Vol. } \\
\left(\mathrm{m}^{3}\right)\end{array}$ & \\
\hline 0,455 & 0,455 & $0 \%$ & 1,084 & 1,084 & $0 \%$ & 1,372 & 1,372 & $0 \%$ & 0,516 & 0,515 & $0 \%$ & 0,732 & 0,732 & $0 \%$ \\
\hline
\end{tabular}

Based on the comparison of the value of measured rainwater and the potential volume of calculated rainwater, the highest gap is only about $0 \%$. This comparison shows that in the rainy season, all the rainwater that falls on the roof can be collected entirely. Evaporation values can be ignored if rainwater collection is done in the rainy season. Based on the results of the quality analysis, the falling rainwater can be used as water for hygiene sanitation by the Minister of Health Regulation number 32 of 2017. The value of rainwater quality collected regarding several physicals, biological and chemical elements are presented in Table 4

Table 4. Physical, biological and chemical elements

\begin{tabular}{cccccc}
\hline No. & Parameter / Variable & Unit & Quality standard & Values & Explanation \\
\hline 1 & Turbidity & NTU & 25 & 2.02 & accepted \\
\hline 2 & Total Dissolved Solid & $\mathrm{mg} / \mathrm{l}$ & 1000 & 20.48 & accepted
\end{tabular}




\begin{tabular}{cccccc}
\hline 3 & Temperature & ${ }^{0} \mathrm{C}$ & Air temperature \pm 3 & 27.5 & accepted \\
\hline 4 & Taste & \multicolumn{5}{c}{ tasteless } & tasteless & accepted \\
\hline 5 & Smell & odorless & odorless & accepted \\
\hline \multicolumn{7}{c}{ BIOLOGICAL ELEMENT } \\
\hline 6 & Total Coliform & CFU/100 ml & 50 & 6.1 & accepted \\
\hline \multicolumn{7}{c}{ CHEMICAL ELEMENT } \\
\hline 7 & $\mathrm{pH}$ & $\mathrm{mg} / \mathrm{l}$ & $6.5-8.5$ & 4.4 & not accepted \\
\hline 8 & Iron & $\mathrm{mg} / \mathrm{l}$ & 1 & $<0.110$ & accepted \\
\hline 9 & Hardness & $\mathrm{mg} / \mathrm{l}$ & 500 & 3.69 & accepted \\
\hline 10 & Lead & $\mathrm{mg} / \mathrm{l}$ & 0.05 & $<0.021$ & accepted \\
\hline \multicolumn{7}{c}{ Calcium } & $\mathrm{ADDITIONAL} \mathrm{PARAMETERS}$ & \\
\hline 11 & $\mathrm{mg} / \mathrm{l}$ & - & 3.36 & - \\
\hline 12 & Magnesium & $\mathrm{mg} / \mathrm{l}$ & - & 0.233 & - \\
\hline
\end{tabular}

Visual observations show that rainwater is colorless so that it can be considered acceptable following the requirements even though it is not measured exactly. Additional parameters are tested to determine the content of other minerals contained in the following rainwater with levels. Some parameter values are below the standard maximum limit from the Minister of Health Regulation Standard number 32 of 2017. Turbidity 2.02 NTU from standard 25 NTU, total dissolved solid $20.48 \mathrm{mg} / \mathrm{l}$ from standard 1000 $\mathrm{mg} / \mathrm{l}$, total coliform $6.1 \mathrm{CFU} / 100 \mathrm{ml}$ from standard $50 \mathrm{CFU} / 100 \mathrm{ml}$, iron $<0.110 \mathrm{mg} / \mathrm{l}$ from standard 1 $\mathrm{mg} / \mathrm{l}$, hardness $3.69 \mathrm{mg} / \mathrm{l}$ from standard $500 \mathrm{mg} / \mathrm{l}$, and lead $<0.021 \mathrm{mg} / \mathrm{l}$ from standard $0.05 \mathrm{mg} / \mathrm{l}$. The result qualifies for sanitation hygiene based on the standard. $\mathrm{pH}$ value 4.4 does not qualify the water quality standards for sanitation hygiene because it has little value so that other treatments are needed to increase $\mathrm{pH}$ levels. Acidic $\mathrm{pH}$ values are affected by the decomposition of organic materials such as leaves and animal feces on the roof. Rainwater also does not have enough minerals for drinking water.

\section{Conclusion and Recommendation}

The average calculation of potential rainwater is $0.582 \mathrm{~m}^{3} /$ month assuming $30 \%$ lost of rainwater due to evaporation. Based on observations during the study carried out (January to May 2018), from the roof area of $96.72 \mathrm{~m}^{2}$, the average volume of collected rainwater as much as $0.831 \mathrm{~m}^{3} / \mathrm{month}$. If the rainwater harvesting process is carried out during the rainy season, neglected water loss due to evaporation because the collected water is $100 \%$ of the amount of water that falls on the roof.

Some parameter values such as turbidity $2.02 \mathrm{NTU}$, total dissolved solid $20.48 \mathrm{mg} / \mathrm{l}$, total coliform 6.1 CFU/100 ml, iron < $0.110 \mathrm{mg} / \mathrm{l}$, hardness $3.69 \mathrm{mg} / \mathrm{l}$, and lead $<0.021 \mathrm{mg} / \mathrm{l}$ are below the standard maximum limit from the Minister of Health Regulation Standard number 32 of 2017. The result qualifies for sanitation hygiene based on standard except for $\mathrm{pH}$ value 4.4. The quality of collected rainwater will qualify the standards as water for sanitation hygiene by first carrying out a low $\mathrm{pH}$ raising process for example by flowing it into a medium that has high lime content. The sedimentation method can reduce turbidity and total dissolved solids.

\section{Acknowledgments}

Authors wishing to acknowledge assistance or encouragement from colleagues, particular work by technical staff and financial support from State Polytechnic of Lampung.

\section{References}


Al-Khatib, I. A., Al Zabadi, H., \& Saffarini, G. (2017). Radon in harvested rainwater at the household level, Palestine. Journal of Environmental Radioactivity, 169-170, 192-196. https://doi.org/10.1016/j.jenvrad.2017.01.014

An, K. J., Lam, Y. F., Hao, S., Morakinyo, T. E., \& Furumai, H. (2015). Multi-purpose rainwater harvesting for water resource recovery and the cooling effect. Water Research, 86, 116-121. https://doi.org/10.1016/j.watres.2015.07.040

Campisano, A., Butler, D., Ward, S., Burns, M. J., Friedler, E., DeBusk, K., ... Han, M. (2017). Urban rainwater harvesting systems: Research, implementation and future perspectives. Water Research, 115, 195-209. https://doi.org/10.1016/j.watres.2017.02.056

Indonesia Health Minister Regulation number 32 (2017). Quality Standards for Environmental Health and Health Requirements for Water for Sanitary Hygiene, Swimming Pool, and Public Baths. Jakarta. https://depkes.go.id

Kharisma, Resti, Ananto Yudono, \& Rita Tahir Lopa. (2016). Pemanfaatan Rainwater Harvesting (Pemanenan Air Hujan) Berbasis Low Impact Development (Studi Kasus: Kawasan Pendidikan FT-UH Gowa). Temu Ilmiah IPLBI proceeding.

Lee, K. E., Mokhtar, M., Mohd Hanafiah, M., Abdul Halim, A., \& Badusah, J. (2016). Rainwater harvesting as an alternative water resource in Malaysia: potential, policies, and development. Journal of Cleaner Production, 126, 218-222. https://doi.org/10.1016/j.jclepro.2016.03.060

Lizárraga-Mendiola, L., Vázquez-Rodríguez, G., Blanco-Piñón, A., Rangel-Martínez, Y., \& GonzálezSandoval, M. (2015). Estimating the Rainwater Potential per Household in an Urban Area: Case Study in Central Mexico. Water, 7(9), 4622-4637. https://doi.org/10.3390/w7094622

Mahmood, A., \& Hossain, F. (2017). Feasibility of managed domestic rainwater harvesting in South Asian rural areas using remote sensing. Resources, Conservation and Recycling, 125, 157-168 https://doi.org/10.1016/j.resconrec.2017.06.013

Nachshon, U., Netzer, L., \& Livshitz, Y. (2016). Land cover properties and rainwater harvesting in urban environments. Sustainable Cities and Society, 27, 398-406. https://doi.org/10.1016/j.scs.2016.08.008

Rosmin, N., Jauhari, A. S., Mustaamal, A. H., Husin, F., \& Hassan, M. Y. (2015). Experimental Study for the Single-stage and Double-stage Two-bladed Savonius Micro-sized Turbine for Rainwater Harvesting (RWH) System. Energy Procedia, 68, 274-281. https://doi.org/10.1016/j.egypro.2015.03.256 